\title{
Investigation and Characterization of Soil for Riv- er Bank Filtration System
}

\author{
VijayaKumar $\mathrm{H}^{1}$, Nagaraj S Patil ${ }^{2}$, Sanjeev Sangami ${ }^{3}$ \\ Civil Engineering Department, UBDTCE, Davanagere, India \\ ${ }^{2}$ Civil Engineering Department, VTU, Belagavi, India \\ ${ }^{3}$ Civil Engineering Department, JCE, Belagavi, India \\ vijaykumarhhalli@gmail.com
}

\begin{abstract}
Soil study has been done to check soil suitability for River Bank Filtration (RBF). A Somlapura village on the bank of Tungabhadra River is selected as study site. In study site 3 different soil samples were collected from 3 different locations to understand the characteristics of soils at a river bank (i.e. Soil texture and permeability). The report of grain size analysis of these 3 samples showed that the soil consists of gravel and sand, which are porous in nature. The permeability test results of soil samples 1,2 , and 3 are $1.16 \times 10^{-3} \mathrm{~cm} / \mathrm{sec}$, $7.67 \times 10^{-3} \mathrm{~cm} / \mathrm{sec}$, and $3.87 \times 10^{-3} \mathrm{~cm} / \mathrm{sec}$ respectively. The maximum permeability of soil sample 2 at site 1 is $7.67 \times 10^{-3} \mathrm{~cm} / \mathrm{sec}$. The soil which has the maximum permeability is more likely to be suitable for the River Bank Filtration application.
\end{abstract}

Keywords:River Bank Filtration, Soil texture, Porosity, Permeability

\section{Introduction}

The texture and permeability of soil plays vital role in defining fitness of a location for implementation of RBF technique. Soil investigations may be performed into two methods: the first is known as reconnaissance (surface investigation) and the second is known as sub surface investigation. The second method is adopted to check soil suitability for implementation River Bank Filtration System. River Bank Filtration is type of water purification method by allowing water to pass through the bank of river or lake; it is then drawn off by extraction wells drilled on the bank of river or lake. In this system bank material acts as a porous medium through which water seeps. Therefore, it is necessary to understand the properties of this porous medium. A study was conducted by Adlan et al., in 1757[1] to find the characteristics of the soil on a Sungai Perak riverbank for unlike strata of a well and 3 nearby observation wells - $\mathrm{OW}_{2}, 3$, and 5. Size distributions of soil particles and permeability values were found from sieve analysis \&Permeameter respectively. Similar study related to soil analysis of borehole near Kerian River, Malaysia [2] featured clay, sandy clay loam and sandy loam. A study on an aquifer with multi-layers, characteristic of sedimentary deposit of riverbank at Korea $[3,4]$, to find the hydrologic characteristics. Many studies were 
conducted on river bank projects and they proved that, river bank sand material used as filter material [5]. From available research works, it is found that soil texture and its permeability will play important role in deciding the water quality and a yield from a RBF well. The present study is to assess the grain size and permeability of the selected soil samples to check its suitability for RBF system on the bank of Tungabhadra River, Karnataka, India.

\section{Study Area}

A Somlapura village on the bank of Tungabhadra River is selected as a study site. Somlapura is a small village of Ranebennur (tq.), Haveri(dist.), Karnataka state, India. It is situated $48 \mathrm{~km}$ towards an East of district headquarters, $20 \mathrm{~km}$ from Ranebennur and $319 \mathrm{~km}$ from capital of state i.e., Bangalore. According to 2011 census the population of the village is 1484 . The Figurel displays the geographical position of study area.

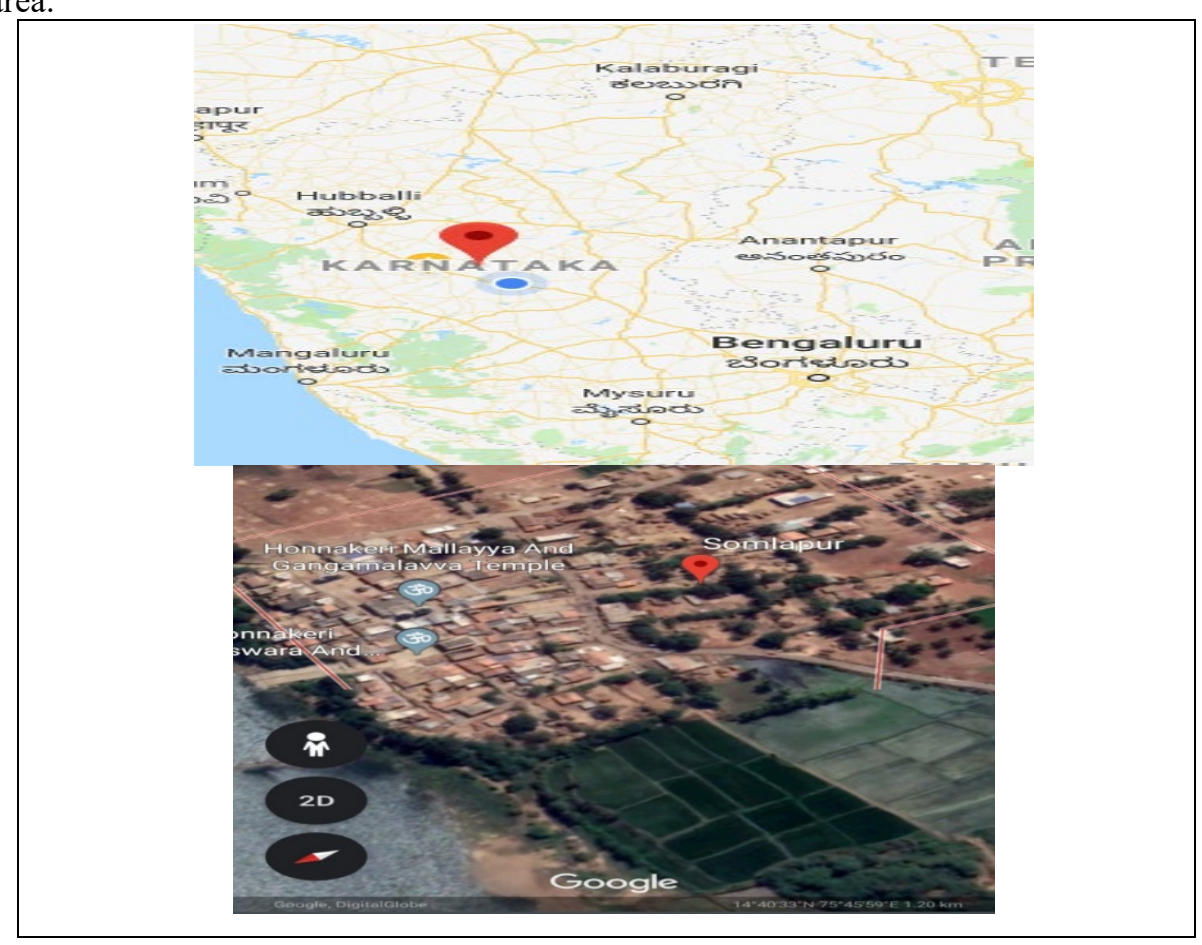

Fig.1.Location of the Study Area 


\section{$3 \quad$ Methodology}

Soil samples were obtained from the study site during the construction and development of the two RBF wells. The coordinate of the RBF1 is $14^{\circ} 40^{\prime} 29.0^{\prime \prime}$ North and $75^{\circ} 46^{\prime} 38.6^{\prime \prime}$ East and the coordinate of the RBF2 is $14^{\circ} 40^{\prime} 27.8^{\prime \prime N}$ North and $75^{\circ} 46^{\prime} 32.9^{\prime \prime}$ East. The soil is obtained from a depth of meter, as the bit pierces into a ground surface. A soil collected is conveyed to a Soil Laboratory to study its characteristics. The methodology followed for the present study is shown in Figure 2.

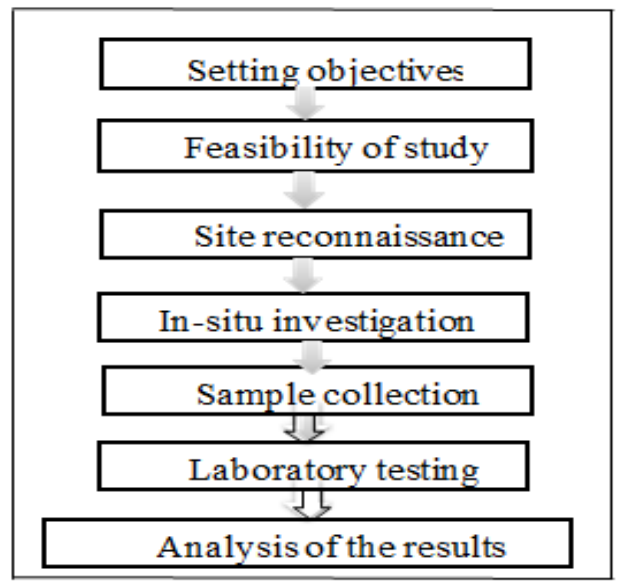

Fig. 2. Work Flow

\section{Experimental Results}

(A) Sieve Analysis: The grain size or sieve analysis of soil sample helps to know about its texture based on which the porosity and permeability of soil sample depends. Tables 1, 2, \& 3 indicate the values of Grain Size Analysis Test.

Table 1. Grain Size test results of sample (1)

\begin{tabular}{|c|c|c|c|c|}
\hline $\begin{array}{l}\text { Sieve size in } \\
\mathrm{mm}\end{array}$ & $\begin{array}{l}\text { Mass of soil re- } \\
\text { tained }(\mathrm{g})\end{array}$ & $\begin{array}{l}\% \text { mass re- } \\
\text { tained }\end{array}$ & $\begin{array}{l}\text { Cumulative \% } \\
\text { retained }\end{array}$ & $\%$ finer \\
\hline 4.75 & 140 & 14 & 14 & 86 \\
\hline 2 & 270 & 27 & 41 & 59 \\
\hline 1 & 328 & 32.8 & 73.8 & 26.2 \\
\hline 0.6 & 108 & 10.8 & 84.6 & 15.4 \\
\hline 0.3 & 97 & 9.7 & 94.3 & 5.7 \\
\hline
\end{tabular}




\begin{tabular}{|c|c|c|c|c|}
\hline 0.15 & 38 & 3.8 & 98.1 & 1.9 \\
\hline 0.075 & 10 & 1 & 99.1 & 0.9 \\
\hline pan & 9 & 0.9 & 100 & 0 \\
\hline
\end{tabular}

The shape of distribution curve of grain-size of soil shows the degree of uniformity of soil. A steeper curve shows more uniform soil. Hence, the distribution curve is also known as 'uniformity curve'. Quantitatively speaking, the soil uniformity is defined by its "Coefficient of Uniformity" $\mathrm{Cu}$.

$C_{u}=\frac{D_{60}}{D_{10}}$ Where, D60 $=60 \%$ finer size. And D10 $=10 \%$ finer size. Soil is considered to be very uniform, if $\mathrm{Cu}<5$; it is of medium uniformity, if $\mathrm{Cu}=5$ to 15 ; and it is very non-uniform or well-graded, if $\mathrm{Cu}>15$. One more factor which signifies a shape of distribution curve is "Coefficient of Curvature", $C C$, is given by: $C_{C}=\frac{\left(D_{30}\right)^{2}}{D_{10} \cdot D_{60}}(2)$ Where, D30 $=30 \%$ finer size. Cc must be 1 to 3 for a well-graded soil. On an average for, Sands $\mathrm{Cu}=10$ to 20 , Silts $\mathrm{Cu}=2$ to 4 . The soil sample 1, depth ranging from 3.5-5.0 $\mathrm{m}$ had D10 $=0.408 \mathrm{~mm}, \mathrm{D} 30=1.084 \mathrm{~mm}$, and D60 $=2.605 \mathrm{~mm}, \mathrm{Cu}=5.061$ and $\mathrm{Cc}=1.394$, according to Indian standard code of practice (IS: 460-1962) the soil is categorized as Poorly graded sands and gravelly sands, little or no fines. The particle size distribution curve of this soil is displayed in Figure3. 


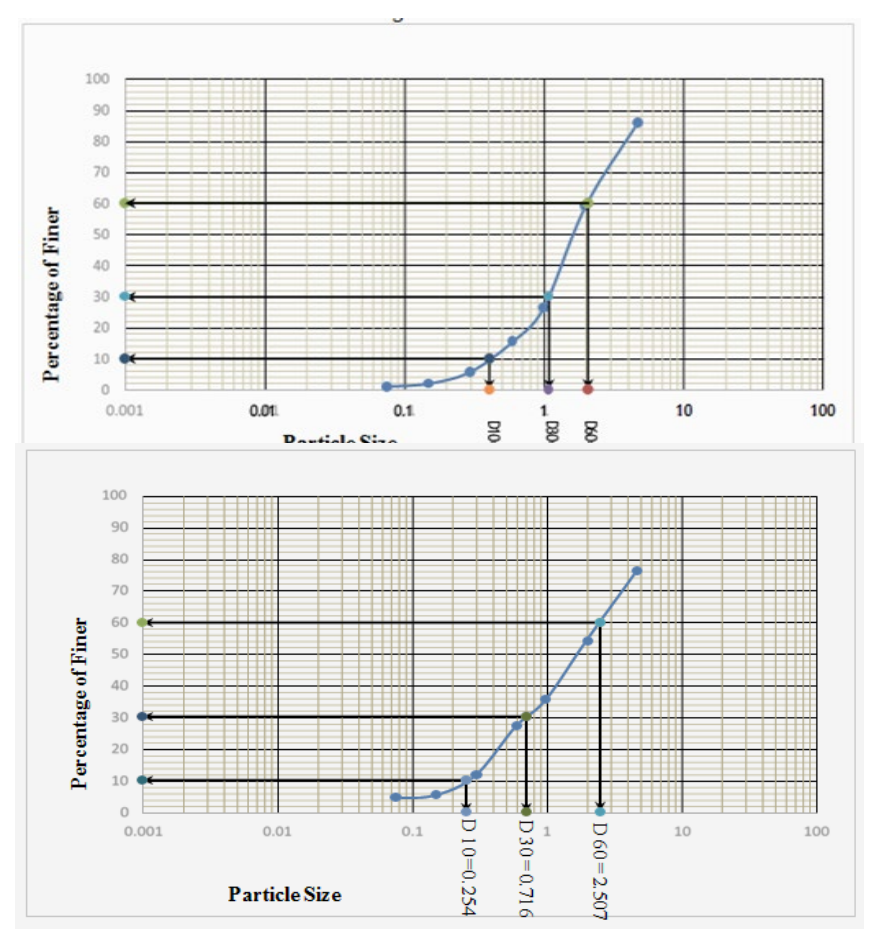

Fig. 3.Grain Size distribution curve of Sample (1), Fig 4. Grain Size Distribution Curve of Sample 2

Table 2. Grain Size analysis test for sample (2)

\begin{tabular}{|c|c|c|c|c|}
\hline sieve size in mm & Mass of soil retained $(\mathrm{g})$ & \% mass retained & Cumulative \% retained & $\%$ finer \\
\hline 4.75 & 236 & 23.6 & 23.6 & 76.4 \\
\hline 2 & 222 & 22.2 & 45.8 & 54.2 \\
\hline 1 & 187 & 18.7 & 64.5 & 35.5 \\
\hline 0.6 & 84 & 8.4 & 88.5 & 27.1 \\
\hline 0.3 & 156 & 15.6 & 94.7 & 11.5 \\
\hline 0.15 & 62 & 6.2 & 95.5 & 5.3 \\
\hline 0.075 & 8 & 0.8 & 99.9 & 4.5 \\
\hline pan & 44 & 4.4 & & 0.1 \\
\hline
\end{tabular}


The soil sample 2 had $\mathrm{D}_{10}=0.254 \mathrm{~mm}, \mathrm{D}_{30}=0.716 \mathrm{~mm}$, and $\mathrm{D}_{60}=2.507 \mathrm{~mm}, \mathrm{C}_{\mathrm{u}}$ $=9.870$ and $C_{c}=0.8050$, according to IS: $460-1962$ the soil is categorized as Poorly graded sands and gravelly sands, little or no fines. The particle size distribution curve of this soil is displayed in figure 4 .

Table 3. Grain Size Analysis Test for Sample 3

\begin{tabular}{|c|c|c|c|c|}
\hline sieve size in mm & Mass of soil retained (g) & \% mass retained & Cumulative \% retained & \% finer \\
\hline 4.75 & 370 & 37 & 37 & 63 \\
\hline 2 & 214 & 21.4 & 58.4 & 41.6 \\
\hline 1 & 148 & 14.8 & 80 & 26.8 \\
\hline 0.6 & 68 & 6.8 & 87.6 & 12.4 \\
\hline 0.3 & 76 & 7.6 & 94 & 6 \\
\hline 0.15 & 64 & 6.4 & 95.4 & 4.6 \\
\hline 0.075 & 14 & 1.4 & 100 & 0 \\
\hline pan & 46 & 4.6 & & \\
\hline
\end{tabular}

The soil sample 3 had $\mathrm{D}_{10}=0.231 \mathrm{~mm}, \mathrm{D}_{30}=1.378 \mathrm{~mm}$, and $\mathrm{D}_{60}=4.208 \mathrm{~mm}, \mathrm{C}_{\mathrm{u}}$ $=18.2164$ and $C_{c}=1.953$, according to IS: $460-1962$ the soil is categorized as Poorly graded sands and gravelly sands, little or no fines. The particle size distribution curve of this soil is displayed in Figure 5.

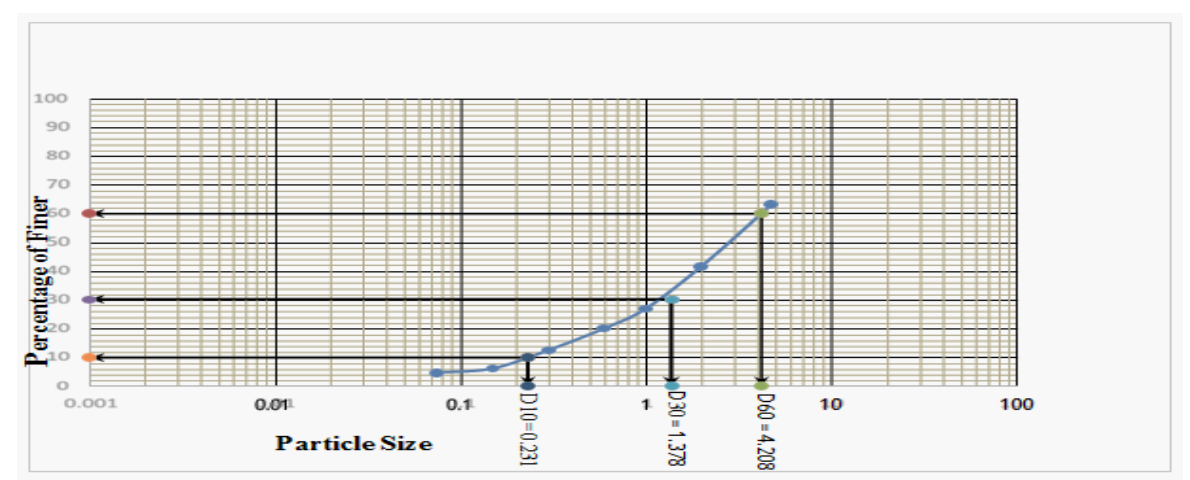

Fig. 5. Grain Size Distribution Curve of sample 3 
From the grain size analysis of sample $1,2 \& 3$, it is found that soil grains are dominated with gravel and sand particles. This shows that soil is more suitable for RBF with high porosity.

(B) Permeability Test:The permeability of the soil sample defines its capacity to transmit water through its pore spaces. Table 4 indicates the typical values of $\mathrm{K}$ for various types of soils. And tables 5, 6, \& 7 shows the results of test conducted using permeameter.

Table 4. Typical Values of $\mathrm{K}$ in $\mathrm{cm} / \mathrm{sec}$

\begin{tabular}{|c|c|c|c|}
\hline Sl. No & Soil type & Value of K cm/Sec & $\begin{array}{c}\text { Relative permeabil- } \\
\text { ity }\end{array}$ \\
\hline 1 & Clean gravel & 1.0 and greater & High \\
\hline 2 & Sand (mixture) & $1 \times 10^{-2}$ to $5 \times 10^{-2}$ & Medium \\
\hline 3 & Fine Sand & $5 \times 10^{-2}$ to $1 \times 10^{-3}$ & Low \\
\hline 4 & Silty sand & $2 \times 10^{-3}$ to $1 \times 10^{-4}$ & Very Low \\
\hline 5 & Clay & $1 \times 10^{-6}$ and smaller & Impervious \\
\hline
\end{tabular}

Table 5.Permeability Test for Sample 1

\begin{tabular}{|c|c|c|c|c|c|c|c|}
\hline $\begin{array}{l}\text { Sl. } \\
\text { No }\end{array}$ & $\begin{array}{r}\mathrm{He} \\
\text { ad of } \\
\text { Water }\end{array}$ & $\begin{array}{l}\text { Volume of } \\
\text { vater collect- } \\
\text { d }\end{array}$ & $\begin{array}{l}\mathrm{Ti} \\
\text { ne }\end{array}$ & $\begin{array}{l}\text { Dis- } \\
\text { charge } \\
\text { sec }\end{array}$ & perlic gradient & $\begin{array}{l}\text { Permeabil- } \\
\text { ity in } \mathrm{cm} / \mathrm{Sec}\end{array}$ & $\begin{array}{l}\text { Avg. per- } \\
\text { meability }\end{array}$ \\
\hline 1 & 222 & 270 & 15 & 18 & 18.5 & 0.0123 & \multirow{3}{*}{$1.16 \times 10^{-3}$} \\
\hline 2 & 222 & 400 & 25 & 16 & 18.5 & 0.0110 & \\
\hline 3 & 222 & 495 & 30 & 16.5 & 18.5 & 0.0113 & \\
\hline
\end{tabular}

Table 6. Permeability Test for Sample 2

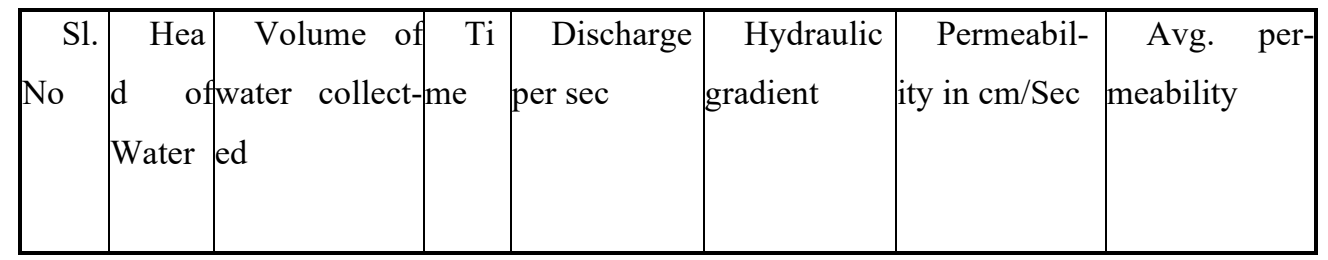




\begin{tabular}{|l|l|l|l|l|l|l|l|}
\hline 1 & 222 & 165 & 15 & 11 & 18.5 & 0.00757 & \multirow{2}{*}{$7.67 \times 10^{-3}$} \\
\cline { 1 - 6 } 2 & 222 & 290 & 25 & 11.6 & 18.5 & 0.00798 & \\
\cline { 1 - 6 } 3 & 222 & 325 & 30 & 10.83333 & 18.5 & 0.00746 & \\
\hline
\end{tabular}

From table 5 it is found that the average value of permeability as $1.16 \times 10-3 \mathrm{~cm} / \mathrm{sec}$, which falls in the category of very low permeability (table 4). From table 6 it is found that the average value of permeability as $7.67 \times 10-3 \mathrm{~cm} / \mathrm{Sec}$, which falls in the category of medium permeability (table 4 ).

Table 7. Permeability Test for Sample 3

\begin{tabular}{|c|c|c|c|c|c|c|c|}
\hline $\begin{array}{l}\text { Sl. } \\
\text { No }\end{array}$ & \begin{tabular}{|r}
$\begin{array}{r}\text { Head } \\
\text { of } \\
\text { ter }\end{array}$ \\
\end{tabular} & \begin{tabular}{|c|} 
Volume of \\
water collected e
\end{tabular} & Tim & $\begin{array}{l}\text { Dis- } \\
\text { charge per } \\
\text { sec }\end{array}$ & Hydrau- & $\begin{array}{l}\text { Permea- } \\
\text { bility } \\
\mathrm{cm} / \mathrm{Sec}\end{array}$ & \begin{tabular}{c|c|} 
Avg. per- \\
in meability
\end{tabular} \\
\hline 1 & 222 & 95 & 15 & 6.33333 & 18.5 & 0.00436 & \multirow{3}{*}{$3.87 \times 10^{-3}$} \\
\hline 2 & 222 & 130 & 25 & 5.2 & 18.5 & 0.00358 & \\
\hline 3 & 222 & 160 & 30 & 5.33333 & 18.5 & 0.00367 & \\
\hline
\end{tabular}

From table 7 it is found that the average value of permeability as $3.87 \times 10$ $3 \mathrm{~cm} / \mathrm{Sec}$, which falls in the category of low permeability (table 4). Sample 2 has highest permeability of $7.67 \times 10-3 \mathrm{~cm} / \mathrm{Sec}$ out of the three values. Hence sample 2 is found to be suitable for RBF to get high yield of water.

\section{Conclusions}

Following conclusions drawn from the experimental study on different soil samples collected from various parts of selected site. The grain size analysis of sample 1 , $2 \& 3$ showed that soil consist of gravel and sand. The permeability of soil sample1, $2, \& 3$ are $1.16 \times 10^{-3} \mathrm{~cm} / \mathrm{sec}, 7.67 \times 10^{-3} \mathrm{~cm} / \mathrm{sec}$, and $3.87 \times 10^{-3} \mathrm{~cm} / \mathrm{sec}$ respectively. The maximum permeability of soil at site 1 is $7.67 \times 10^{-3} \mathrm{~cm} / \mathrm{sec}$. The soil which has the maximum permeability (sample 2) is more likely to be suitable for the River Bank Filtration application. 


\section{References}

1. Adlan, M.N., MAZ, M.R.R., Ghazali, M.F., Selamat, M.R. and Othman, S.Z., 1757. A study on the soil characteristic and properties of riverbank soil samples from Sungai Perak, Kota Lama Kiri, KualaKangsar, Malaysia. In Book of Abstracts (p. 24).

2. Abd Rashid, N.A., Roslan, M.H., Abd Rahim, N., Abustan, I. and Adlan, M.N., 2015. Artificial barrier for riverbank filtration as improvement of soil permeability and water quality. Journal Technology, 74(11)..

3. Kim, J.W., Choi, H. and Lee, J.Y., 2005. Characterization of hydrogeologic properties for a multi-layered alluvial aquifer using hydraulic and tracer tests and electrical resistivity survey. Environmental geology, 48(8), pp.991-1001.

4. Sheets, R.A., Darner, R.A. and Whitteberry, B.L., 2002. Lag times of bank filtration at a well field, Cincinnati, Ohio, USA. Journal of Hydrology, 266(3-4), pp.162-174.

5. Schubert, J., 2002. Hydraulic aspects of riverbank filtration-field studies. Journal of Hydrology, 266(3-4), pp.145-161.

6. K. D. Singh and S. T. Ahmed, "Systematic Linear Word String Recognition and Evaluation Technique," 2020 International Conference on Communication and Signal Processing (ICCSP), Chennai, India, 2020, pp. 0545-0548, doi: 10.1109/ICCSP48568.2020.9182044

7. S. T. Ahmed and K. K. Patil, "An investigative study on motifs extracted features on real time big-data signals," 2016 International Conference on Emerging Technological Trends (ICETT), Kollam, 2016, pp. 1-4, doi: 10.1109/ICETT.2016.7873721.

8. S. T. Ahmed, H. K. Priyanka, S. Attar and A. Patted, "Cataract density ratio analysis under color image processing approach," 2017 International Conference on Intelligent Computing and Control Systems (ICICCS), Madurai, 2017, pp. 178-180, doi: 10.1109/ICCONS.2017.8250705 